\title{
Executive Control of Bureaucracy and Presidential Cabinet Appointments in East Asian Democracies
}

\author{
Don S. Lee \\ University of Nottingham \\ don.lee@nottingham.ac.uk
}

Accepted for publication in Regulation \& Governance on 20 January 2018

\begin{abstract}
This article examines the role of cabinet appointments in controlling the bureaucracy in presidential democracies. I demonstrate how administrative challenges stemming from the structure of the bureaucracy shape presidential choice of ministers. Analyzing a sample of four East Asian cases from 1986 through 2013, I find that presidents are more likely to select ministers from the civil service as bureaucracies are more professionalized, controlling for several political factors. Further evidence from qualitative interviews and case studies suggests that, in professionalized systems equipped with a sizable pool of talent but lacking responsiveness, presidents tend to promote ideologically aligned senior civil servants. However, in politicized systems, where presidents easily obtain responsiveness but face a low level of competence, policy experts tend to be selected from outside the bureaucracy. My findings have important implications for the regulatory governance and state capacity of East Asia, demonstrating the value of balancing between responsiveness and competence.
\end{abstract}




\section{Introduction}

Cabinet ministers play a central role in policy formulation and implementation of every democratic government. Existing studies of government formation in presidential systems have examined executive appointments mainly in the context of a president's legislative strategy. Presidents are more likely to appoint partisan ministers when they have limited policymaking power in order to strengthen support for their policy agenda (Amorim Neto 2006). When the ruling party does not control a legislative majority, presidents tend to concede cabinet posts to other parties, thereby forming executive coalitions (Cheibub 2007). When presidents have effective control of their party, they are more likely to appoint copartisans versus nonpartisans to the cabinet (Martínez-Gallardo and Schleiter 2015).

Recent emerging literature on presidential cabinet appointments has begun exploring the rationale of choosing ministers beyond partisanship. The selection of so-called "nonpartisans" to cabinets provides presidents with certain advantages for managing their policy programs. Presidents can enjoy a high degree of ministerial loyalty by naming nonpartisan ministers as their appointments are not tied to the cabinet's legislative support (Dowding and Dumont 2009). Moreover, by appointing nonpartisan ministers, presidents can take advantage of their policy expertise since professional background and technical skill are typical selection criteria for nonpartisans in the recruitment process. Nonpartisans are therefore prevalent in presidential cabinets and composed of individuals with diverse backgrounds (Amorim Neto and Samuels 2010; Camerlo and Pérez-Liñán 2015). Despite the significant contribution of the recent research on nonpartisan ministers, overlooked in this literature is a president's delegation concerns in policy implementation. In particular, there has been little comparative study of how presidents can employ cabinet resources to monitor and control bureaucrats. 
This article fills this gap by examining the role of presidential cabinet appointments in controlling the bureaucracy in East Asia. ${ }^{1}$ In East Asia, where a majority of democracies have popularly elected presidents, there is wide cross-country variation in the proportion of ministers who are selected from the bureaucracy. To account for this variation, I build my theoretical framework on the "administrative presidency" approach (Heclo 1977; Lewis 2008, 2011; Moe 1985b; Nathan 1983; Rudalevige 2005; Waterman 1989), focusing on how presidents exert one of their important powers - the authority to staff top executive posts in the bureaucracy - to influence policy implementation and make agencies serve them. ${ }^{2}$ As shown in the data description below, presidents in East Asia have systematically selected ministers from either inside or outside the bureaucracy depending on the bureaucratic structure they face; incentives for selecting one type of minister over the other have also differed across countries and evolved over time.

In this article, I explore how administrative challenges stemming from the structure of the bureaucracy itself can shape presidential cabinet appointment decisions. Focusing on the institutional aspects of bureaucratic structure, I demonstrate that presidents face different types of administrative challenges according to how civil servants are recruited and promoted in the bureaucratic apparatus. Adopting the Weberian conceptualization of meritocratic civil service as a spectrum, there are professionalized systems characterized by merit-based recruitment and predictable procedures for promotion at one end, while politicized systems, at the other end, use political affiliation as the key selection criterion for executive posts. In a professionalized

\footnotetext{
${ }^{1}$ See Baum (2011) for the use of administrative procedure acts as a mechanism for controlling bureaucracy in the East Asian context.

${ }^{2}$ Among the definitions of politicization, recruitment-related definition is most clear and commonly referenced. Some definitions in this perspective are "party political favouritism in recruitment and promotion of civil servants" (Ståhlberg 1987, 368) and "the [political leader's] act of increasing the number and penetration of appointees" (Lewis 2008, 2).
} 
bureaucracy, presidents have a sizable pool of talent but should be concerned about career bureaucrats' programmatic support for their policy agenda. On the other hand, facing a politicized bureaucracy, presidents have more direct influence over the civil service but should be concerned about a lower level of professional expertise. By applying this approach to the East Asian context, where there is considerable variation in the institutional characteristics of bureaucracy, we can observe whether presidents adjust their cabinet appointments to deal with the common trade-off between responsiveness and competence in a transitional bureaucracy (Aberbach and Rockman 1994; Hojnacki 1996).

In describing the importance of controlling government agencies via a president's cabinet appointments, I examine presidential choice of ministers from within or outside the civil service in 21 administrations of four East Asian countries (South Korea, Taiwan, the Philippines and Indonesia) for over two decades. My analyses of original datasets show that presidents are more likely to choose ministers from the civil service when bureaucracies are professionalized, but are less likely to do so in politicized civil service systems. Relying on qualitative interviews and case studies, I provide further evidence about the appointment mechanism for agency control. In professionalized systems, where chief executives enjoy a sizable pool of talent but need to enhance responsiveness, presidents tend to promote ideologically aligned senior civil servants. On the other hand, in politicized systems, where chief executives easily obtain responsiveness but face a low degree of competence, presidents tend to seek experts from outside the bureaucracy for cabinet appointments.

My analysis makes important contributions to the literature on regulatory governance as well as comparative politics. First, this study speaks to the emerging literature on the role of nonpartisans in government with a new approach by clearly showing how existing variation in 
the institutional characteristics of bureaucracy affects presidential choice of ministers from inside or outside the bureaucracy. Second, by analyzing an administrative dimension in cabinet choices of East Asian presidential democracies that have been rarely studied in comparative perspective, this study contributes new evidence to the debate over who controls the bureaucracy and how, extending this research beyond the context of American politics.

In the next section, I discuss the delegation problems presidents face in controlling bureaucrats and explore political appointments as solutions, drawing on the "administrative presidency" approach in American politics. I then outline my theoretical framework which leverages variation in the institutional structure of the bureaucracy and suggest that certain bureaucratic structures, such as professionalized or politicized systems, pose different types of administrative challenges and shape presidential incentives to choose ministers from inside or outside the civil service. After analyzing these hypothesized relationships, I discuss my findings and draw conclusions regarding cross-case variation in bureaucratic structure and presidential choice of nonpartisan ministers.

\section{Delegation Problems and Appointment Mechanism for Agency Control}

In contemporary democracies, citizens elect representatives to the government, and civil servants implement policy on behalf of the elected officials. This basic principal-agent framework provides insight into the policy process: from voters (principals) all the way to bureaucrats as ultimate agents who formulate and implement policy (Strøm 2000). This framework is particularly useful to compare parliamentary and presidential democracies, the two common and pure types of democratic regimes, because it allows us to identify the circumstances where agency problems are more likely to happen. As illustrated in Figure 1, the political processes of 
the two systems described into delegation mechanisms display a clear contrast. While a principal-agent relationship in parliamentary democracy is linked in a single chain of delegation from voters to executive agencies (Strøm 2000), presidential democracy features a more complicated delegation sequence from citizens to civil servants (Shugart 2006).

[Figure 1 about here]

In Figure 1, two discrete steps in the processes are notable as major points of difference between the two systems. First, voters in parliamentary democracies have single agents as they elect their own representatives to a parliament, whereas voters in presidential democracies generally have multiple competing agents as they separately elect legislators and presidents who represent a different set of voters. Second, civil servants in parliamentary democracies have single principals, their respective cabinet ministers, and are simply accountable to their heads in the department. ${ }^{3}$ However, civil servants in presidential democracies have multiple principals who may place conflicting demands in an attempt to hold their agents accountable (Moe and Caldwell 1994; Strøm 2000). The rest of this section further elaborates on the latter point in order to discuss the mechanisms of controlling civil servants in presidential democracies.

The question of who controls executive agencies under multiple-principal conditions has long been debated among scholars of American politics. The ongoing discussion makes it clear that no single player is dominant as a principal, and no single control mechanism in operation is

\footnotetext{
${ }^{3}$ Deviation from the Westminster model also generates multiple principals to agents in parliamentary democracy. In a coalition government, a common type of parliamentary government where a prime minister has to select cabinet ministers from coalition partners, how to hold civil servants accountable is a primary concern for the chief executive. Often, delegation to coalition partners may lead to high costs that a prime minister suffers due to the divergence of preferences and the difficulty of sanctions against coalition members (see Strøm 2000; Thies 2001).
} 
most effective in the political process. ${ }^{4}$ The fact that presidents compete against the legislature for the accountability of executive agencies but are typically held accountable for the performance of the whole government has a significant implication for executive control of the bureaucracy (Moe 1985b): Chief executives will exert considerable effort to influence policy implementation by employing their central authority to fill top executive posts (Lewis 2008, 2011; Waterman 1989). The question is, how do presidential appointments help them to gain control of executive agencies?

According to the "administrative presidency" model developed by scholars of American politics, presidents seek to strategically enhance personnel responsiveness as well as organizational competence of bureaucracies and guide career civil servants to meet their political objectives (Heclo 1977; Moe 1985b; Nathan 1983; Rudalevige 2005). One typical approach is politicization, whereby presidents can increase the number and location of administrative positions occupied by their appointees in the executive branch and rely more on the personnel (Lewis 2008; Moe 1985b; Rudalevige 2002; Weingast 2005). ${ }^{5}$ Politicization is particularly attractive to chief executives as a control mechanism because the power of appointment, anchored in a formal presidential power, provides more leverage in personnel management vis-àvis any other authority granted to chief executives. Presidents can take direct action to shore up responsiveness by appointing people based on loyalty or may improve competence by stressing policy expertise in appointments (Moe 1985b, 245).

\footnotetext{
${ }^{4}$ The long and inconclusive debate on this topic has resulted in a broad array of studies on political control of the bureaucracy, from the Congressional dominance argument to the presidential control and autonomous bureaucracy arguments. In terms of control mechanisms, they include ex ante tools such as appointments, administrative procedures, executive orders, and legislation as well as ex post instruments such as oversight, judicial review of agency rulings, and budgets.

${ }^{5}$ The other approach is centralization, whereby presidents create and expand parts of the executive branch that are most closely allied with them (e.g., Executive Office of the President) and then give their policy staff a central role.
} 
This line of reasoning, based on the U.S. presidency literature, suggests political appointments are a particularly effective strategy for presidents in influencing agency behavior and policy outcomes. First, presidents find that expectations surrounding their performance are often greater than their authority and institutional capacity (Cronin 1975; Lowi 1985; Moe 1985b; Neustadt [1960] 1990). Given this imbalance, presidents have strong incentives to enhance their capacity by initiating reforms and making adjustments in the administrative apparatus around them. However, in acting upon these incentives, presidents find that their resources are wholly inadequate as they are constrained by stumbling blocks, such as political and bureaucratic opposition, institutional inertia, and time pressures (Moe 1985b, 240-244). Second, in the organizational perspective, executive agencies seem embedded within the executive branch. Yet, the agencies are not under the entire control of the chief executive but are rather caught in between the president and the legislature that often disagree about the evaluation of an agency's performance and the direction of any policy change by the agency (Weingast 2005). For presidents, it is difficult to persuade legislative members to support their policy but also tough to induce relevant agencies to follow executive directions faithfully under multiple principals (Nathan 1983, 2). More importantly, the role of political appointees has proven effective and consequential in executive control of agency behavior (Calvert, McCubbins, and Weingast 1989; Moe 1982, 1985a; Wood 1990; Wood and Waterman 1991, 1994). Political appointees in top executive positions, which require decision-making and management abilities in the policy process, can change agencies and substantially affect policy outcomes (Lewis 2008). Ideally, having political appointees allows a steady infusion of talent, ensures an influx of new ideas, and counteracts inertia (Bok 2003, 265). In sum, it is the inadequacy of institutional capacity in the presidency, a conflict of interest within the executive branch, and the key role of political 
appointees that generate the appointment mechanism for agency control we observe in presidential democracies.

\section{Presidential Control of Bureaucracy in Comparative Perspective}

Although the discussion in the previous section provides important insights into the role of political appointments as potential solutions to agency problems, all of this literature is based on the premise that presidents will choose top executive appointees from their ideological allies, given the static nature of American bureaucracy. Yet, existing variation in the structure of the bureaucracy across countries produces an additional dimension to presidential personnel distribution, positing different types of administrative challenges to presidents of other nations. Despite the important role of political appointments in controlling agency behavior in presidential democracies, there has been little comparative research on this subject.

Prior neglect of an administrative dimension from the discussion of presidential cabinet appointments in the comparative literature is understandable. In Latin America, where presidentialism is the central aspect of its constitutional history and the dominant body of comparative research on presidential cabinet formation has emerged, central bureaucracies are staffed mostly by those who lack professional qualifications (Riggs 2009). ${ }^{6}$ Without sufficient variation in bureaucratic structure across the region, scholars of cabinet studies, when accounting for nonpartisan appointments, might have not paid particular attention to the relationship between the characteristics of bureaucratic structures presidents face and their choice of

\footnotetext{
${ }^{6}$ Two common types of bureaucrats in Latin America are retainers - long-term employees with no qualifications and politicos - short-term employees with no qualifications (Riggs 2009, 157-158).
} 
nonpartisans from the civil service. ${ }^{7}$ In contrast, a broad spectrum exists in professionalization among bureaucratic structures in East Asia, and such variation may affect presidential incentives to select nonpartisan ministers from inside versus outside the bureaucracy. What we need is a comparative framework that explains how such variation in bureaucratic systems accounts for variation in presidential patterns of appointing top agents.

In this article, I argue that the key institutional characteristics of bureaucracy - how civil servants are recruited and promoted - shape presidential incentives to appoint cabinet ministers to whom they delegate authority to control bureaucrats. In describing the main features of different personnel systems across bureaucracies, I adopt the "Weberianness Scale," a simple measure of the degree to which civil service systems are characterized by merit-based recruitment and predictable procedures for promotion (Evans and Rauch 1999). At one end of the scale, a highly professionalized bureaucracy is characterized by "meritocratic recruitment through competitive examinations," "civil service procedures for hiring and firing rather than political appointments and dismissals," and "filling higher levels of the hierarchy through internal promotion" (Rauch and Evans 2000, 50-51). At the other end, a highly politicized bureaucracy utilizes political affiliation as the key selection criterion for executive posts throughout the organization hierarchy, giving chief executives vast influence over the agencies through hiring and firing political appointees. Across the continuum of personnel systems, presidents face different types of agency problems ranging from responsiveness to competence. Presidents enjoy a sizeable pool of talented personnel in professionalized bureaucracies which tend to be insulated from political influence. In contrast, presidents may wield extensive control over politicized bureaucracies while suffering these agencies' "lower human capital" and "greater

\footnotetext{
${ }^{7}$ Such literature defines nonpartisans as either "technocrats" who have an independent policy agenda or "outsiders" who are personally loyal to the chief executive (Camerlo and Pérez-Liñán 2015, 317) but makes no clear connections between these appointees and the characteristics of bureaucratic structures.
} 
difficulty with recruitment and retention of high-capacity bureaucrats" (Krause, Lewis, and Douglas 2006, 772).

Presidents, facing these two contrasting types of bureaucracies, will make different appointment decisions for agency control. In professionalized bureaucracies, a sizable pool of competent civil servants provides clear opportunities for presidents to efficiently accomplish their policy goals. However, presidents also want their policies implemented closely in line with their preferences (Dowding and Dumont 2009, 2014; Hahm, Jung, and Lee 2013). As bureaucracies are more professionalized, civil servants, who are likely to stay in the government longer than their chief executives, may have weaker incentives to align with presidential policy preferences. One way to handle this problem is through selectively promoting senior civil servants who are ideologically compatible with the chief executive. The choice of the so-called "administrative loyalists" (Nathan 1983; Weingast 2005; Wilson 1989) as cabinet ministers helps presidents to manage agency behavior in a twofold way. First, since these administrative loyalists are reliable agents as well as professionals in their fields, presidents can empower them to deliver chief executives' policy commitments. Second, given their experience and long-term careers within the organization, administrative loyalists are better positioned to manage rankand-file civil servants in merit-based bureaucracies on a president's behalf (Evans and Rauch 1999; Jung, Moon, and Hahm 2008). Therefore, by promoting these administrative loyalists into top executive positions, presidents can expect to enhance responsiveness while taking advantage of the talent pool.

By contrast, presidents can enjoy vast influence over the organization in politicized bureaucracies. In cases where political appointments run deep into the organization hierarchy, presidents gain direct and greater control over the bureaucracy. Yet, they also encounter the 
dilemma of a limited pool of competence within the bureaucracy. Under a system based on ad hoc criteria, it is difficult to bring individual motivations in line with organizational, long-term goals (Evans and Rauch 1999), which implies a lower chance of effectiveness in bureaucratic performance. Politicizing recruitments and promotions means that a large number of civil servants are likely to leave once newly elected presidents take office. Irregular hiring and promotion standards as well as unpredictable career trajectories will further deter civil servants from putting much effort into policy implementation. Hence, it is relatively rare to see highcapacity bureaucrats promoted into top executive positions in highly politicized systems. In most cases, chief executives in these systems will recruit executive talent by staffing the cabinet with experts from outside the bureaucracy.

In sum, I predict that there will be significantly more ministers from the civil service in professionalized systems than in politicized systems. This line of logic leads to the following hypothesis:

As bureaucracies are more professionalized, presidents are more likely to appoint ministers from the civil service; when civil service systems are more politicized, presidents are more likely to appoint ministers from outside the bureaucracy.

In general, democratic presidents are motivated by broader policy concerns when they choose whom to run their ministries and treat the state bureaucracy as an organization to help advance their policy goals. In this sense, I assume that presidents consider the administrative dimension in cabinet choices to manage their delegation concerns in policy implementation. In achieving their administrative purposes, each appointment decision is a trade-off between responsiveness and competence, and its scope depends on the degree of professionalization in bureaucratic structure. Although the staffing of top executive posts provides only a partial picture 
of presidential efforts to contain the risk of agency loss in delegating policy implementation, a comparative analysis of the institutional characteristics of bureaucracy in East Asian presidential democracies will still contribute new evidence to our knowledge of a president's strategic appointment decisions.

\section{Data and Method}

In this section, I empirically test my hypothesis using original data collected for quantitative analysis. The central argument points to the importance of variables that affect presidential incentives to appoint cabinet ministers to accomplish their competing goals in public administration. To test the proposed hypothesis, I constructed an original dataset of presidential cabinets and ministers in East Asia through several criteria. First, the Polity score, which lists a political regime ranging from 6 to 10 as democracy, is used to determine a set of presidential democracies in East Asia and the respective beginning year of democracy for these cases. ${ }^{8}$ I then chose all cases where the country's constitution grants presidents the authority to appoint and dismiss ministers (Hicken and Kasuya 2003; Shugart and Carey 1992). ${ }^{9}$ The dataset includes 21 administrations in four East Asian presidential democracies for the following periods: South Korea (1988-2013), Taiwan (1993-2013), the Philippines (1986-2013), and Indonesia (19992013). ${ }^{10}$ Second, within these cases, the composition of the cabinet with a list of ministers was observed with information from the CIA Directory of Chiefs of State and Cabinet Members of Foreign Governments and the Political Handbook of the World. Information on the backgrounds

\footnotetext{
${ }^{8}$ http://www.systemicpeace.org/polity/polity4.htm.

${ }^{9}$ Mongolia and East Timor were excluded due to the limited power of presidents over cabinet formation.

${ }^{10}$ Indonesia before 2005 and Taiwan before 1997 are not pure presidential democracies as Presidents Abdurrahman Wahid (1999-2001) and Megawati Sukarnoputri (2001-04) of Indonesia and President Lee Teng-hui (1993-1996) of Taiwan were not directly elected by the national constituency. I test whether my results are robust after excluding these periods and running the same analysis with directly-elected presidents only.
} 
of ministers was collected from academic publications, local archives, news reports, and websites. ${ }^{11}$ Since restructuring of the executive branch occurred in some administrations, I used the organization chart described on the official government websites of each case to obtain information about the size of cabinets. $^{12}$

The main dependent variable, Ministers from Civil Service, is the proportion of ministers from the civil service in the cabinet, which is recorded based on the yearly observation of cabinet composition for each country. It is defined as ministers who took career-track positions in the civil service through national exams or open recruitment and served as a career civil servant prior to cabinet appointment. ${ }^{13}$ Figure 2 presents data on this variable from 21 administrations in four East Asian presidential democracies. It clearly demonstrates that there is systematic variation across four cases: Career civil servants are markedly more prevalent in South Korean and Taiwanese cabinets than Philippine and Indonesian cabinets. On average, the cross-country variation ranges from the lows of 8.5 percent (Indonesia) and 10 percent (Philippines) to the highs of Taiwan (23.5 percent) and South Korea (36.1 percent). Although there is some withincountry variation, these trends are generally consistent across the observations of presidential administrations in each case.

[Figure 2 about here]

\footnotetext{
${ }^{11}$ See a list of sources in the appendix.

${ }^{12}$ In Indonesia, the size of cabinets ranges from 29 to 35; in the Philippines, from 21 to 24; in South Korea, from 16 to 25; and in Taiwan, from 29 to 34. The dataset includes all portfolios in the cabinet except independent agencies, where agency heads have a fixed term and are not affected by cabinet reshuffle decisions (e.g., Central Bank and Central Election Commission). See a list of ministries in the appendix.

${ }^{13}$ For details of civil service recruitment in East Asia, see Berman (2011), Berman, Moon, and Choi (2010), and Moon and Hwang (2013).
} 
The key independent variable is Bureaucracy Quality which measures the degree to which the state bureaucracy tends to be autonomous and run by a transparent and rule-bound mechanism for hiring and promotion. The original data are from ratings by the International Country Risk Guide (ICRG) of "Bureaucratic Quality," one of the indicators of the Quality of Government. The scale runs from 0 to 4 , with the highest marks given to countries where the national bureaucracy is autonomous, transparent, and operates under clear rules for employing and advancing personnel, whereas countries which lack the buffering effect of a professionalized bureaucracy and tend to be interrupted by political pressure in policy implementation receive low points. ${ }^{14}$ ICRG ratings on bureaucratic quality, previously used for research on the performance of the national bureaucracy (e.g., Knack and Keefer 1995), are regularly updated and recorded based on the yearly observation of bureaucratic structure in the world. For this analysis, I use a scale from 0 to 1 , normalized from the original 0-4 scale by the Quality of Government Institute. ${ }^{15}$

In addition, I also use indices of bureaucratic structure by Rauch and Evans (2000) as a benchmark against ratings from the ICRG on bureaucratic quality. The bureaucratic structure indices, employed as an alternative measure for robustness, are constructed based on survey responses from country experts. I adopt two indices - Merit (the extent to which recruitment is meritocratic at the entry level, ranging 0-1) and Career (the extent of internal promotion, ranging 0-1) - and sum up each of these index scores within my respective countries (see Rauch and

\footnotetext{
${ }^{14} \mathrm{http} / / /$ www.prsgroup.com/ICRG.aspx. ICRG methodology describes how to measure ratings on bureaucratic quality as follows: "The institutional strength and quality of the bureaucracy is another shock absorber that tends to minimize revisions of policy when governments change. Therefore, high points are given to countries where the bureaucracy has the strength and expertise to govern without drastic changes in policy or interruptions in government services. In these low-risk countries, the bureaucracy tends to be somewhat autonomous from political pressure and to have an established mechanism for recruitment and training. Countries that lack the cushioning effect of a strong bureaucracy receive low points because a change in government tends to be traumatic in terms of policy formulation and day-to-day administrative functions (http://www.prsgroup.com/wp-content/uploads/2012/11/ icrgmethodology.pdf)."

${ }^{15}$ http://www.qog.pol.gu.se.
} 
Evans 2000, 54-56). Likewise, high points should be given to countries where the national bureaucracy is characterized by "meritocratic recruitment through competitive examinations, civil service procedures for hiring and firing rather than political appointments and dismissals, and filling higher levels of the hierarchy through internal promotion" (Rauch and Evans 2000, 50-51).

Figure 3 displays the simple bivariate correlation between ICRG ratings on bureaucratic quality and the proportion of ministers from the civil service. The scatter plot indicates a positive relationship lending support for my hypothesis: As bureaucracies are more professionalized, there are more ministers from the civil service in presidential cabinets; when bureaucracies are more politicized, there are fewer ministers from the civil service in the cabinet. This hypothesis will be tested through more sophisticated multivariate analyses, but Figure 3 provides initial support for my argument.

[Figure 3 about here]

I further control for six variables that may affect presidential strategy for appointing cabinet ministers. These can be broadly categorized as constitutional powers, partisan strength, and political and economic contexts. The first control variable, Constitutional Powers, measures formal powers granted to the president. It is a common parameter of presidential power and may have a positive impact on the appointment of ministers from the civil service. Presidents who have a powerful formal authority to enact bills unilaterally may have stronger incentives to focus on policy implementation, thereby choosing more ministers with professional backgrounds such as civil service experience (see Amorim Neto 2006). I adopt the classification by Shugart and 
Carey (1992) and apply their ordinal scales to information from the constitutions of the four East Asian democracies and other academic sources. This classification divides the formal powers into two categories - legislative and non-legislative powers - which have multiple types of powers within each category. The overall measure is the sum of the individual scores (ranging from 0 to 4 ) of each subtype of powers within the two categories. ${ }^{16}$ The measure ranges from 9 (Indonesia) to 21.5 (South Korea).

The second control variable, Presidents' Support in Legislature, measures a president's partisan powers based on their capacity to shape or dominate the policymaking process that emanates from the president's standing in relation to the party system (Shugart and Mainwaring 1997). The president's ability to achieve their political agenda relies on the approval of a majority of legislative members (Cox and Morgenstern 2002). It is likely to have a positive relationship with the appointment of ministers from the civil service. When their party controls a legislative majority, presidents have weaker incentives to concede cabinet posts to form a coalition government (Cheibub, 2007) and have more leeway to work toward managing policy performance by appointing more professional ministers such as career civil servants. As a measure of a president's partisan strength, I employ the proportion of seats occupied by the president's party in the lower or only chamber.

The final four control variables relate to political and economic contexts: Electoral Cycle, Term Limits, Inflation, and Age of Democracy. The third control variable, Electoral Cycle, measures the number of months left until the end of the president's current term of office. It is likely to have a negative relationship with the appointment of ministers with civil service backgrounds, because the political dynamics of executive-legislative relations are shaped by the fixed electoral calendar and shift over the course of the president's term (Altman 2000). Newly

\footnotetext{
${ }^{16}$ See Shugart and Carey $(1992,150)$ for details.
} 
inaugurated presidents enjoy a presidential honeymoon and may want to push new agendas with party-affiliated people in the cabinet, whereas presidents at later stages in their terms tend to stabilize an administration and will try to avoid becoming a lame duck by appointing ministers from the civil service (see Altman 2000; Martínez-Gallardo 2012, 2014). The fourth control variable, Term Limits, measures whether a president can run for re-election or not. The president's appointment strategy also depends on the limit of presidential terms because presidents limited to a single term (South Korea and the Philippines) are likely to have different appointment approaches from two-term presidents who can seek re-election (Taiwan and Indonesia). This is a dichotomous variable which gives 1 if presidents are eligible for re-election, and 0 otherwise. It is likely to be negatively associated with the appointment of ministers from the civil service, because presidents who can run for re-election have stronger incentives to hire more party-affiliated ministers to shore up the support of the legislature or their own party. I also control for Inflation using the monthly change in the consumer price index. ${ }^{17}$ As observed in the 1997 Asian financial crisis, presidents tend to increase the number of technocratic ministers in response to economic calamity. Adopting the proxy measure used to account for this possibility (e.g., Martínez-Gallardo and Schleiter 2015), I control for this economic context factor in the analysis. Finally, I also control for Age of Democracy, which is the number of years since the country’s democratic transition, because new democracies with an immature party system can be more conducive to nonpartisanship in the cabinet (Amorim Neto and Strøm 2006). If this is truly what happens in East Asia, it is likely to be positively correlated with the appointment of nonpartisan professionals with civil service backgrounds. Table 1 provides summary statistics for the independent and control variables included in the analysis.

\footnotetext{
${ }^{17}$ https://www.ceicdata.com/en/statistics/Consumer-Price-Index-CPI.
} 
[Table 1 about here]

As displayed in Figures 2 and 3 above, my sample includes yearly observations on four cases for more than two decades on average. To estimate the proportion of ministers from the civil service, I use general linear models, which address estimation issues concerning the timeseries cross-sectional structure of the dataset (Zorn 2001). ${ }^{18}$ These models are widely used to estimate cabinet formation for proportion data (e.g., Alemán and Tsebelis 2011; EscobarLemmon and Taylor-Robinson 2005; Martínez-Gallardo and Schleiter 2015). I estimate robust standard errors with first-order autocorrelation correction within each panel to account for the possibility of heteroscedasticity and autocorrelation issues. For robustness checks, I run the same analysis with individual-level data, including 1,257 ministers across the four East Asian countries between 1986 and 2013, using logistic regression models to estimate the likelihood of ministers from the civil service being present in the cabinet. In these additional models, I use a dichotomous variable ( 1 if ministers are from the civil service; 0 otherwise) as my dependent variable and estimate robust standard errors clustered on each country.

\section{Findings and Analysis}

Table 2 shows estimated coefficients of bureaucratic quality and control variables from the multivariate regression analysis. In Model 1, I test my hypothesis using a general linear model to measure the proportion of ministers from the civil service in presidential cabinets. In Model 2, I run the same model, substituting the Rauch and Evans index as the key independent variable on

\footnotetext{
${ }^{18}$ The generalized least-squares (GLS) estimator of the random effects model is close in spirit to the fixed effects model. With time averages of the regressors in the panel model, efficient GLS estimation can lead to estimators that equal the fixed effects estimators (Cameron and Trivedi 2005, 719). In my analysis, each of the independent variables based on monthly observations for original data is now averaged per year within the variable.
} 
bureaucratic quality for the ICRG ratings. As indicated above, the Rauch and Evans index is used as a benchmark against the ICRG ratings. The inclusion of the Rauch and Evans index, however, causes the number of cases to drop to three due to unavailability of information on Indonesia. Models 3 and 4 test the proposed hypothesis using logistic models to estimate the likelihood of ministers from the civil service being present in the cabinet. Each model runs the same analysis with the ICRG ratings (Model 3) and the Rauch and Evans index (Model 4) as my main independent variable. This modeling decision allows for checking the robustness of the results in Models 1 and 2.

[Table 2 about here]

The results from Table 2 support my prediction about how bureaucratic quality shapes presidential strategy for appointing cabinet ministers. In Model 1, the effect of the ICRG ratings on bureaucratic quality is positive and statistically significant. For an increase in the normalized score of the ICRG ratings from its observed minimum to maximum values, there is an expected increase of 4.3 ministers from the civil service in the cabinet on average (15.6 percent of the average size of the cabinet), holding all other variables constant. ${ }^{19}$ This finding therefore supports my hypothesis. ${ }^{20}$

Figure 4 illustrates the predicted effect of increasing professionalization in bureaucratic structure, indicating that these characteristics positively affect presidential appointments of ministers from the civil service. When the degree of professionalization is low and political

\footnotetext{
${ }^{19}$ The average size of the cabinet is 27.25 which is based on the size of the cabinet formed at the beginning of the term in the most recent administrations, as of 2013, from four East Asian democracies: South Korea (17), Taiwan (34), the Philippines (23), and Indonesia (35).

${ }^{20}$ The model excluding indirectly-elected presidents (Indonesia before 2005 and Taiwan before 1997) produced substantively similar results.
} 
affiliation is the main selection criterion for executive posts, there is a low proportion of ministers promoted from the bureaucracy. On the other hand, in professionalized bureaucracies that utilize merit-based recruitment through competitive examinations and civil service procedures for hiring and firing, there is a high proportion of ministers recruited from the bureaucracy.

[Figure 4 about here]

Model 2 is similar to Model 1 but includes the Rauch and Evans index as the key independent variable on bureaucratic quality. In Model 2, the effect of the Rauch and Evans index of bureaucratic structure is positive and statistically significant. For an increase in the score from its observed minimum to maximum values, there is an expected increase of 7.3 ministers from the civil service in the cabinet on average (26.8 percent of the average size of the cabinet), holding all control variables constant. This finding confirms the result from Model 1 and provides further support for my hypothesis.

Models 3 and 4 test the hypothesis employing logistic models for dichotomous outcomes. I report these models here in order to compare with the results in Models 1 and 2 and check their robustness. In Model 3, the coefficient estimate of the ICRG ratings is positive and statistically significant, indicating that the presence of ministers from the civil service is more likely in presidential cabinets as bureaucracies are more professionalized. Likewise, the coefficient of the Rauch and Evans index is positive and statistically significant in Model 4, indicating that as civil service systems are more autonomous and established, we are more likely to observe ministers with civil service career backgrounds in the cabinet. 
The six control variables have the predicted effects, but only a few of the coefficients consistently reach statistical significance across models in Table 2. First, the effect of Constitutional Powers is positive and statistically significant in most model specifications. Presidents have more leeway to focus on policy effectiveness when they have a strong formal authority in policymaking, which leads to increased appointments of ministers from the civil service. Second, in Models 3 and 4, I find that newly inaugurated presidents are less likely to include ministers with civil service backgrounds in the cabinet, whereas presidents at the later stages of their terms are more likely to choose ministers from the civil service. The political dynamics of executive-legislative relations, which change over the electoral cycle, are indeed proven to affect the president's appointment strategy. While other control variables related to political and economic contexts, such as Term Limits, Inflation, and Age of Democracy, also attain statistical significance, these variables perform inconsistently across different model specifications.

\section{Explaining Ministers' Ideologies and Backgrounds: Interviews and Case Studies}

The results in Table 2 are based on the estimation of the proportion of ministers from the civil service being positively associated with bureaucratic quality. However, the logic behind my argument is more specific concerning ministers' ideologies and backgrounds. My prediction is that, when choosing nonpartisan ministers, presidents tend to promote senior civil servants who are ideologically compatible with them in professionalized systems; in politicized systems, presidents tend to select policy experts from outside the bureaucracy. Therefore, I further analyze the process of selecting individual ministers when presidents are faced with the two contrasting types of civil service systems. For this analysis, I rely on personal interviews with ministers and 
case studies as well as my original individual-level data. In this section, I first describe the key institutional features of the civil service system in each case and discuss the type of agency problem presidents tend to face in controlling bureaucrats. I then provide an explanation of ministerial appointment patterns in each country since its democratic transition.

Among the four East Asian cases discussed in this article, there is considerable variation in the degree of professionalization in bureaucratic structure. While South Korea and Taiwan are characterized by well-established bureaucracies, Indonesia and the Philippines have civil service systems that depend more on political influence in their recruitment and promotion processes. A merit-based career civil service system was institutionalized in South Korea long before its democratization in 1987 (Rho and Lee 2010). Taiwan's civil service system is also based on merit-based recruitment and promotion (Cheng and Haggard 2001). In contrast, the Philippine system has been highly responsive and relatively subservient to the political leadership (Cariño 1992; Endriga 2001). Indonesia's civil service is in transition after democratization, striving for the establishment of a more institutionalized body but still being characterized by a complicated accountability mechanism for human resource management.

With this array of professionalization in bureaucratic structure, we can observe how such variation poses different types of administrative challenges for presidents in East Asia. South Korea's civil service system, which is well-known for its high levels of professional competence, has the problem of bureaucratic rigidity emerging after democratization. Taiwan's merit-based personnel administration system has generated an intra-branch conflict with democratic presidents who saw administrative reforms against the closed nature of civil service as inevitable after democratic transition. In contrast, in the Philippines, political interference results in more direct control over bureaucrats, but it also causes governance issues, thereby serving as 
stumbling blocks to government performance (Berman 2011). In Indonesia's current system, characterized by no established mechanism to centralize personnel choices with transparent standards in employee selection, presidents have huge room for political interference but need to make reform efforts for improving the accountability of personnel management (Moon and Hwang 2013).

How have East Asian presidents adjusted their cabinet appointments to handle the responsiveness versus competence trade-off in a transitional bureaucracy? To investigate the process, I sought the views of cabinet members who served in different ministries across presidential administrations in South Korea. ${ }^{21}$ Insights from these interviews reveal factors contributing to the way individual ministers are considered and selected in the Korean context. First, in the prescreening process, a list of finalists is prepared for a given post, and presidents select candidates whose political ideology and policy positions are compatible with theirs. In meritocratic bureaucracies, political appointments are often characterized by hybrid appointments where merit is accompanied by subjective political judgments. ${ }^{22}$ Many senior civil servants in South Korea are vetted through a multi-step process where the president reviews "whether a candidate's political beliefs and policy preferences fall in the acceptable range" (Lee, Moon, and Hahm 2010, 82S). A set of biographical, familial, and educational backgrounds is used as a part of such judgments. ${ }^{23}$ Once chosen, presidents expect ministers with civil service backgrounds to smoothly control highly professional personnel groups in the bureaucratic organization as lower-level bureaucrats will be more amenable to their senior careerists. ${ }^{24}$ Head

\footnotetext{
${ }^{21}$ Specifically, of the 15 ministers I contacted, 10 ministers responded. I do not claim that this sample is representative of all cabinet members, but maintain that it is not too small a cohort to derive useful insights. The interviewees are listed in the appendix.

${ }^{22}$ http://siteresources.worldbank.org/PUBLICSECTORANDGOVERNANCE/Resources/2857411345485407865/Recruitment.pdf (accessed May 15, 2017).

${ }^{23}$ Interview, Korea, September 13 (Choo, Byung-jik), 2013.

${ }^{24}$ Interviews, Korea, September 13 (Choo, Byung-jik) and September 16 (Song, Min-soon), 2013.
} 
of ministry posts are perceived typically as jobs for senior civil servants who share the president's policy orientation.

In the case of Taiwan's merit-based civil service, party influence on its executive organization has been more permeable than that of Korean civil service. Through this influence, presidents facing distrustful bureaucrats have made strategic personnel choices to enhance their claims of accountability. In 2000, when the Democratic Progressive Party (DPP) took control of the government with the election of Chen Shui-bian, the DPP government doubted the veracity of incumbent bureaucrats' accountability to the new party leadership after their decades of civil service under the Kuomintang (KMT). To make the national bureaucracy more loyal and responsive to the DPP administration, Chen deliberately reshuffled the bureaucratic hierarchy by promoting bureau heads and lower ranking government officials to positions as department heads or ministers, some of whom were later recruited as DPP members. ${ }^{25}$ The personnel reshuffle was one way of earning loyalty from promoted civil servants and replacing the previously KMTdominated system with DPP people. When the KMT returned to power with the election of Ma Ying-jeou in 2008, the new administration again showed distrust of incumbent civil servants and accused them of partisan bias (Su 2010). President Ma selectively appointed senior civil servants to his cabinet and brought back some former ministers and government officials who served in the KMT administration more than eight years prior.

In contrast with South Korea and Taiwan, Philippine presidents typically find a pool of executive talent from outside the civil service, as witnessed from the Aquino administration's massive substitution of business personnel for incumbent bureaucrats (Baum 2011). Without much autonomy from political pressures, the Philippine bureaucracy retains few careerists who

${ }^{25}$ Interview, Taiwan, October 21 (Wu, Yu-shan), 2013. 
can reach top executive positions. Instead, Philippine ministers are frequently selected from among external professionals such as professors, business leaders, or legal advisors.

Similarly, presidents in Indonesia generally seek a pool of competence necessary for the administration from outside the civil service. A few departments whose public personnel administration is relatively well-institutionalized, such as foreign policy and finance ministries, see their leaders promoted to top executive positions, but these are rather exceptional cases as the quality is not consistent across ministries. ${ }^{26}$ Many of Indonesian ministers have major careers in academia, business, or even the military prior to their appointment. In Table 3, I present major careers of nonpartisan ministers from outside the bureaucracy across presidential administrations in the Philippines and Indonesia since democratic transition. The centrality of competence to the president's appointment mechanism for controlling bureaucrats is reflected in the pattern of cabinet appointments in both cases. As shown in Table 3, the majority of nonpartisan ministers in Philippine and Indonesian cabinets were professors or business leaders. Combined with legal advisors and security forces commanders, they took about a 90 percent share.

[Table 3 about here]

In sum, my analyses suggest that bureaucratic quality has a significant impact on the executive appointment of cabinet ministers, even controlling for several political and partisan factors that affect presidential strategy for choosing ministers. In particular, a professionalized bureaucracy can enlarge the pool of talented personnel within the civil service, resulting in increased promotions to top executive posts of senior civil servants who are ideologically aligned with presidents. In the case of a politicized system, it provides for presidential discretion in

\footnotetext{
${ }^{26}$ Interviews, Indonesia, June 4 (Hamid Awaluddin), 2013 and June 13 (Juwono Sudarsono), 2013.
} 
directly controlling bureaucrats through political interference, leading to a growing recruitment of external experts from outside the civil service. These findings have significant implications for the state capacity of East Asian democracies, showing the value of carrying out administrative reforms and balancing between political responsiveness and administrative competence. These characteristics not only affect policy implementation with the civil service but also have an important impact on the advancement of a president's broader policy concerns and the public interest.

\section{Conclusion}

The comparative literature on government formation demonstrates that a majority of cabinet members in presidential democracies typically have no affiliation with political parties and tend to have diverse backgrounds (Amorim Neto and Samuels 2010; Camerlo and Pérez-Liñán 2015). These attributes are also common in East Asia, where most democracies have popularly elected presidents. Specifically, professors are popular candidates for cabinet posts, but the presence of civil servants as ministers shows wide cross-country variation among East Asian democracies. Here, I suggest that the choice of cabinet ministers is determined in a dimension beyond legislative strategy, exploring an administrative dimension by focusing on key institutional features of the civil service system. How civil servants are recruited and promoted in the bureaucratic apparatus affects presidential incentives to appoint cabinet ministers to whom they delegate authority to monitor and control civil servants. Faced with professionalized systems, characterized by a sizable pool of talent but a low degree of responsiveness, presidents can choose ministers from the civil service by promoting senior careerists who are ideologically aligned with them. In politicized systems, wherein presidents easily obtain responsiveness but 
face a low level of internal competence, they seek to appoint policy experts from outside the bureaucracy. While I uncover strong evidence of hybrid appointments where objective merit is accompanied by subjective political judgments in professionalized bureaucracies, I am unable to determine whether senior civil servants that were promoted into ministers were all presidents' loyalists. Additional information on individual ministers' policy positions and their ties to the president would do much to further illuminate the appointment mechanisms for controlling bureaucrats (see e.g., Bertelli and Grose 2011).

This article makes some important contributions to the literature on comparative politics and presidential studies, which may travel beyond East Asia. First, my analysis demonstrates how presidents employ cabinet resources to control bureaucrats and manage their delegation concerns in policy implementation. The comparative literature on cabinet formation in presidential democracies has focused mainly on a president's legislative strategy, largely overlooking the administrative dimension of cabinet choices. My research speaks to the emerging literature on the role of nonpartisans in government and contributes a new approach the appointment mechanism for agency control. Second, by analyzing East Asian presidential democracies, which are largely understudied cases in the comparative literature, this article contributes new evidence to the debate over political control of bureaucracy beyond the context of American politics. In particular, my analysis confirms the importance of bureaucratic variables to more precisely infer the factors shaping bureaucratic action and to properly explain the administrative process (Meier and O'Toole 2006). In analyzing presidential efforts to control the bureaucracy and helping to understand the role of cabinet appointments, future research should seek to not only examine whether each of the four East Asian cases demonstrates 
different trajectories of democratic development through in-depth case studies but also expand the number of cases by applying this mechanism to other democracies in Asia and beyond.

Alternatively, other future research agendas exist for scholars of executive control of bureaucracy. One area is to investigate whether the appointment patterns presented in this study hold across different agencies in presidential democracies. Research on cabinet appointments suggests that portfolio allocations help chief executives to fulfill their particular goals and incentives. Yet, the literature on portfolio allocations is still underdeveloped for presidential democracies. Future research on this subject will further improve our understanding of the appointment mechanism for agency control. Another area is applying the appointment mechanism I present in this paper to bureaucrats at the local level and examining its effectiveness. In delegating policy implementation, containing the risk of agency loss is a major concern for governors as well as for presidents. Future research that examines the relationship between institutional characteristics of bureaucracy and patterns of political appointments in state governments will similarly make important contributions to the study of state politics and local governance.

Additionally, future work on the impact of some variation in appointment patterns across countries and over time will have important implications for the quality of governance and the consolidation of democracy. My analysis suggests that cabinet appointments can provide flexible options to enhance responsiveness or organizational competence for chief executives to handle this common trade-off. Yet, experts who are selected from within the civil service and outside of it may perform differently. Anecdotal evidence from the developing world indicates that noncivil service experts perform in a more corrupt way than their civil service counterparts. Further research on this subject will tell whether there is any systematic relationship between experts' 
career backgrounds and their performance, which might leave politicized bureaucracies more vulnerable to producing crummy patronage-based cabinets.

\section{References}

Aberbach, Joel D., and Bert A. Rockman. 1994. "Civil Servants and Policymakers: Neutral or Responsive Competence?" Governance 7 (4): 461-469.

Alemán, Eduardo, and George Tsebelis. 2011. "Political Parties and Government Coalitions in the Americas." Journal of Politics in Latin America 3 (1): 3-28.

Altman, David. 2000. "The Politics of Coalition Formation and Survival in Multi-party Presidential Democracies: The Case of Uruguay, 1989-1999." Party Politics 6 (3): 259-283.

Amorim Neto, Octavio. 2006. "The Presidential Calculus: Executive Policy Making and Cabinet Formation in the Americas." Comparative Political Studies 39 (4): 415-440.

Amorim Neto, Octavio, and David Samuels. 2010. "Democratic Regimes and Cabinet Politics: A Global Perspective." Revista Ibero-Americana de Estudos Legislativos 1 (1): 10-23.

Amorim Neto, Octavio, and Kaare Strøm. 2006. "Breaking the Parliamentary Chain of Delegation: Presidents and Non-Partisan Cabinet Members in European Democracies." British Journal of Political Science 36 (4): 619-643.

Baum, Jeeyang Rhee. 2011. Responsive Democracy: Increasing State Accountability in East Asia. Ann Arbor, MI: University of Michigan Press.

Berman, Evan M., M. Jae Moon, and Heungsuk Choi, ed. 2010. Public Administration in East Asia: Mainland China, Japan, South Korea, and Taiwan. New York, NY: CRC Press.

Berman, Evan M., ed. 2011. Public Administration in Southeast Asia. New York, NY: CRC Press.

Bertelli, Anthony M., and Christian R. Grose. 2011. "The Lengthened Shadow of Another Institution? Ideal Point Estimates for the Executive Branch and Congress." American Journal of Political Science 55 (4): 767-781.

Bok, Derek. 2003. Government Personnel Policy in Comparative Perspective. In For the People: Can We Fix Public Service, ed. J. D. Donahue and J. S. Nye. Washington, DC: Brookings Institution Press.

Calvert, Randall, Mathew D. McCubbins, and Barry R. Weingast. 1989. "A Theory of Political Control and Agency Discretion." American Journal of Political Science 33 (3): 588-611. 
Camerlo, Marcelo, and Aníbal Pérez-Liñán. 2015. "The Politics of Minister Retention in Presidential Systems: Technocrats, Partisans, and Government Approval." Comparative Politics 47 (3): 315-333.

Cameron, A. Colin, and Pravin K. Trivedi. 2005. Microeconometrics: Methods and Applications. Cambridge: Cambridge University Press.

Cariño, Ledivina V. 1992. Bureaucracy for Democracy: The Dynamics of ExecutiveBureaucracy Interaction during Governmental Transitions. Philippine Institute for Development Studies.

Cheibub, José A. 2007. Presidentialism, Parliamentarism, and Democracy. Cambridge: Cambridge University Press.

Cheng, Tun-jen, and Stephan Haggard. 2001. "Democracy and Deficits in Taiwan: The Politics of Fiscal Policy, 1986-1996." In Presidents, Parliaments, and Policy, ed. S. Haggard and M. D. McCubbins. Cambridge: Cambridge University Press.

Cox, Gary, and Scott Morgenstern. 2002. "Epilogue: Latin America’s Reactive Assemblies and Proactive Presidents." In Legislative Politics in Latin America, ed. S. Morgenstern and B. Nacif. Cambridge: Cambridge University Press.

Cronin, Thomas E. 1975. The State of the Presidency. Boston: Little, Brown and Company.

Dowding, Keith, and Patrick Dumont. 2009. "Structural and Strategic Factors Affecting the Hiring and Firing of Ministers." In The Selection of Ministers in Europe, ed. Keith Dowding and Patrick Dumont. New York, NY: Routledge.

Dowding, Keith, and Patrick Dumont, eds. 2014. The Selection of Ministers around the World. New York, NY: Routledge.

Endriga, Jose N. 2001. "The National Civil Service System of the Philippines." In Civil Service System in Asia, ed. J. P. Burns and B. Bowornwathana. Cheltenham, UK: Edward Elgar.

Escobar-Lemmon, Maria, and Michelle M. Taylor-Robinson. 2005. "Women Ministers in Latin American Government: When, Where, and Why?" American Journal of Political Science 49 (4): 829-844.

Evans, Peter, and James E. Rauch. 1999. "Bureaucracy and Growth: A Cross-national Analysis of the Effects of 'Weberian' State Structures on Economic Growth." American Sociological Review 64 (5): 748-765.

Hahm, Sung Deuk, Kwangho Jung, and Sam Youl Lee. 2013. "Exploring the Determinants of the Entry and Exit of Ministers in Korea: 1980-2008." Governance 26 (4): 657-675. 
Heclo, Hugh. 1977. A Government of Strangers: Executive Politics in Washington. Washington, DC: Brookings Institution Press.

Hicken, Allen, and Yuko Kasuya. 2003. "A Guide to the Constitutional Structures and Electoral Systems of East, South and Southeast Asia." Electoral Studies 22 (1): 121-151.

Hojnacki, William. 1996. "Politicization as a Civil Service Dilemma." In Civil Service Systems in Comparative Perspective, ed. H. A. G. M. Bekke, J. L. Perry, and T. A. J. Toonen. Bloomington, IN: Indiana University Press.

Jung, Kwangho, M. Jae Moon, and Sung Deuk Hahm. 2008. "Exploring the Linkage between Ministerial Leadership and Performance in Korea." Administration and Society 40 (7): 667690.

Knack, Stephen, and Philip Keefer. 1995. "Institutions and Economic Performance: Cross-country Tests Using Alternative Institutional Measures." Economics \& Politics 7 (3): 207-227.

Krause, George A., David E. Lewis, and James W. Douglas. 2006. "Political Appointments, Civil Service Systems, and Bureaucratic Competence: Organizational Balancing and Executive Branch Revenue Forecasts in the American States." American Journal of Political Science 50 (3): 770-787.

Lee, Sam Youl, M. Jae Moon, and Sung Deuk Hahm. 2010. "Dual Faces of Ministerial Leadership in South Korea: Does Political Responsiveness or Administrative Responsibility Enhance Perceived Ministerial Performance?" Administration and Society 42 (1S): 77S-101S.

Lewis, David E. 2008. The Politics of Presidential Appointments: Political Control and Bureaucratic Performance. Princeton, NJ: Princeton University Press.

— 2011. "Presidential Appointments and Personnel." Annual Review of Political Science 14: 47-66.

Lowi, Theodore J. 1985. The Personal President: Power Invested, Promise Unfulfilled. Ithaca, NY: Cornell University Press.

Martínez-Gallardo, Cecilia. 2012. "Out of the Cabinet: What Drives Defections from the Government in Presidential Systems?" Comparative Political Studies 45 (1): 62-90.

_ 2014. "Designing Cabinets: Presidential Politics and Ministerial Instability." Journal of Politics in Latin America 6 (2): 3-38.

Martínez-Gallardo, Cecilia, and Petra Schleiter. 2015. "Choosing Whom to Trust: Agency Risks and Cabinet Partisanship in Presidential Democracies." Comparative Political Studies 48 (2): 231-264. 
Meier, Kenneth J., and Laurence J. O'Toole. 2006. "Political Control versus Bureaucratic Values: Reframing the Debate." Public Administration Review 66 (2): 177-192.

Moe, Terry M. 1982. "Regulatory Performance and Presidential Administration." American Journal of Political Science 26 (2): 197-224.

— 1985a. "Control and Feedback in Economic Regulation: The Case of the NLRB." American Political Science Review 79 (4): 1094-1116.

— 1985b. "The Politicized Presidency." In The New Direction in American Politics, ed. J. E. Chubb and P. E. Peterson. Washington, DC: The Brookings Institution.

Moe, Terry M., and Michael Caldwell. 1994. "The Institutional Foundations of Democratic Government: A Comparison of Presidential and Parliamentary Systems." Journal of Institutional and Theoretical Economics 150 (1): 171-195.

Moon, M. Jae, and Changho Hwang. 2013. "The State of Civil Service Systems in the AsiaPacific Region: A Comparative Perspective." Review of Public Personnel Administration 33 (2): 121-139.

Nathan, Richard P. 1983. The Administrative Presidency. John Wiley \& Sons.

Neustadt, Richard E. 1990. Presidential Power and the Modern Presidents: The Politics of Leadership from Roosevelt to Reagan. Free Press.

Rauch, James E., and Peter B. Evans. 2000. "Bureaucratic Structure and Bureaucratic Performance in Less Developed Countries." Journal of Public Economics 75 (1): 49-71.

Rho, Seung-Yong, and Seung Jong Lee. 2010. "History and Context of Public Administration in South Korea." In Public Administration in East Asia: Mainland China, Japan, South Korea, and Taiwan, ed. E. M. Berman, M. J. Moon, and H. Choi. New York, NY: CRC Press.

Riggs, Fred W. 2009. "Bureaucracy: A Profound Puzzle for Presidentialism." In Bureaucracy and Administration, ed. Ali Farazmand. New York, NY: CRC Press.

Rudalevige, Andrew. 2002. Managing the President's Program: Presidential Leadership and Legislative Policy Formulation. Princeton, NJ: Princeton University Press.

Rudalevige, Andrew. 2005. The New Imperial Presidency: Renewing Presidential Power after Watergate. Ann Arbor, MI: University of Michigan Press.

Shugart, Matthew S. 2006. Comparative Executive-Legislative Relations. In The Oxford Handbook of Political Institutions, ed. R. A. W. Rhodes, S. A. Binder, and B. A. Rockman. Oxford, UK: Oxford University Press. 
Shugart, Matthew S., and John M. Carey. 1992. Presidents and Assemblies: Constitutional Design and Electoral Dynamics. Cambridge, MA: Cambridge University Press.

Shugart, Matthew S., and Scott Mainwaring. 1997. "Presidentialism and Democracy in Latin America: Rethinking the Terms of the Debate." In Presidentialism and Democracy in Latin America, ed. S. Mainwaring and M. S. Shugart. Cambridge: Cambridge University Press.

Ståhlberg, Krister. 1987. "The Politicization of Public Administration: Notes on the Concept, Causes and Consequences of Politicization." International Review of Administrative Sciences 53 (3): 363-382.

Strøm, Kaare. 2000. "Delegation and Accountability in Parliamentary Democracies." European Journal of Political Research 37 (3): 261-289.

Su, Tsai-Tsu. 2010. "Civil Service Reforms in Taiwan." In Public Administration in East Asia: Mainland China, Japan, South Korea, and Taiwan, ed. Evan M. Berman, M. Jae Moon, and Heungsuk Choi. New York, NY: CRC Press.

Thies, Michael F. 2001. "Keeping Tabs on Partners: The Logic of Delegation in Coalition Governments." American Journal of Political Science 45 (3): 580-598.

Waterman, Richard W. 1989. Presidential Influence and the Administrative State. Knoxville: University of Tennessee Press.

Weingast, Barry R. 2005. "Caught in the Middle: The President, Congress, and the PoliticalBureaucratic System." In The Executive Branch, ed. J. D. Aberbach and M. A. Peterson. New York: Oxford University Press.

Wilson, James Q. 1989. Bureaucracy: What Government Agencies Do and Why They Do It. Basic Books.

Wood, B. Dan. 1990. Does Politics Make a Difference at the EEOC? American Journal of Political Science 34 (2): 503-530.

Wood, B. Dan, and Richard W. Waterman. 1991. "The Dynamics of Political Control of the Bureaucracy." American Political Science Review 85 (3): 801-828.

Wood, B. Dan, and Richard W. Waterman. 1994. Bureaucratic Dynamics: The Role of Bureaucracy in a Democracy. Boulder, CO: Westview.

Zorn, Christopher J.W. 2001. "Generalized Estimating Equation Models for Correlated Data: A Review with Applications." American Journal of Political Science 45(2): 470-490. 


\section{Tables and Figures}

FIGURE 1. Delegation Mechanisms under Parliamentary and Presidential Democracy

\section{Parliamentary Democracy}

Voters $\longrightarrow$ Parliament $\longrightarrow$ Prime Minster $\longrightarrow$ Cabinet Minister $\longrightarrow$ Department

\section{Presidential Democracy}

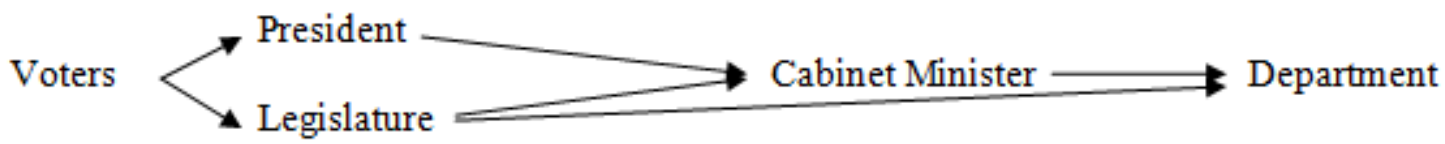

Sources: Shugart (2006), Strøm (2000).

FIGURE 2. Proportion of Ministers from Civil Service across Administrations, by Country

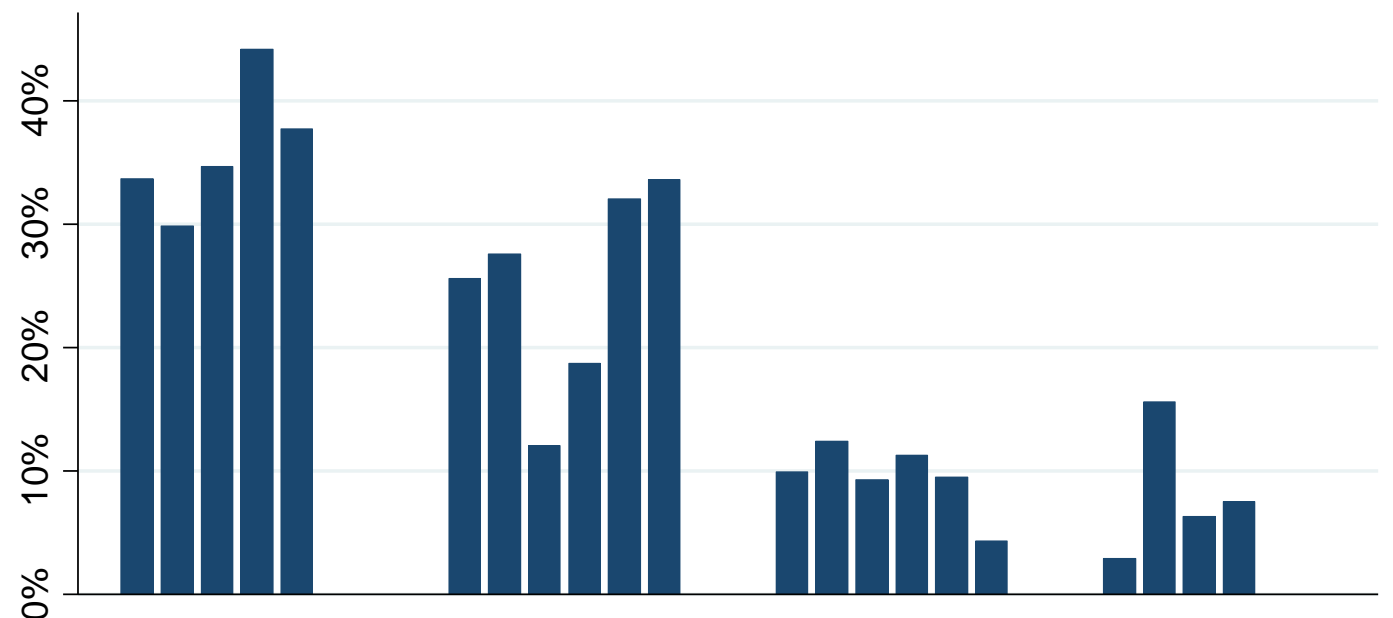

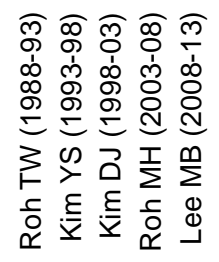

South Korea

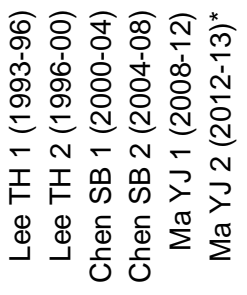

Taiwan

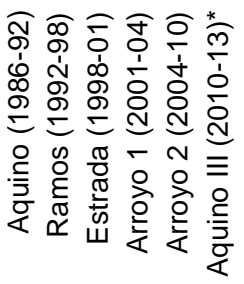

Philippines

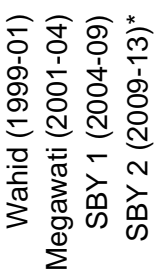

Indonesia

Note: *incumbent as of December 2013. 
FIGURE 3. Quality of Bureaucracy and Proportion of Ministers from Civil Service

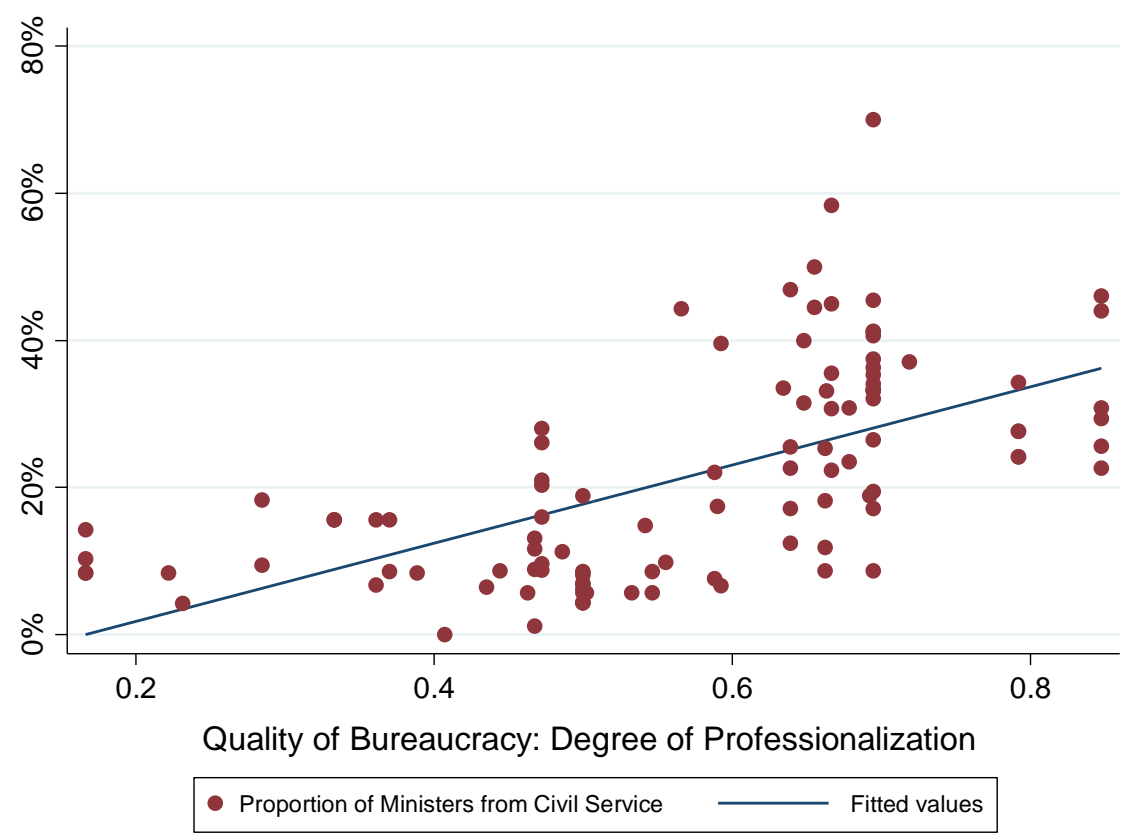

TABLE 1. Descriptive Statistics of Independent and Control Variables

\begin{tabular}{lccccc}
\hline Variable & Obs & Mean & Std Dev & Min & Max \\
\hline ICRG Ratings & 88 & 0.57 & 0.17 & 0.17 & 0.85 \\
Rauch \& Evans Index & 74 & 1.32 & 0.29 & 0.96 & 1.67 \\
Constitutional Powers & 88 & 17.32 & 4.27 & 9.00 & 21.50 \\
Presidents' Support in Legislature & 87 & 0.44 & 0.18 & 0.10 & 0.75 \\
Electoral Cycle & 88 & 36.12 & 18.09 & 1.35 & 71 \\
Term Limits & 80 & 0.20 & 0.40 & 0 & 1 \\
Inflation & 88 & 4.77 & 3.59 & -0.65 & 18.50 \\
Age of democracy & 88 & 12.10 & 7.25 & 1 & 27 \\
\hline
\end{tabular}


TABLE 2. Analysis of Data on Ministers from Civil Service in Presidential Cabinets

\begin{tabular}{|c|c|c|c|c|}
\hline Dependent Variable & $\begin{array}{c}\text { Model 1 } \\
\text { Proportion: } \\
\text { Ministers } \\
\text { from Civil } \\
\text { Service } \\
\end{array}$ & $\begin{array}{c}\text { Model } 2 \\
\text { Proportion: } \\
\text { Ministers } \\
\text { from Civil } \\
\text { Service } \\
\end{array}$ & $\begin{array}{l}\text { Model } 3 \\
\text { Choice: } \\
\text { Ministers } \\
\text { from Civil } \\
\text { Service } \\
\end{array}$ & $\begin{array}{c}\text { Model } 4 \\
\text { Choice: } \\
\text { Ministers } \\
\text { from Civil } \\
\text { Service } \\
\end{array}$ \\
\hline \multicolumn{5}{|l|}{ Bureaucracy Quality } \\
\hline ICRG Ratings & $\begin{array}{l}0.230 * * \\
(0.102)\end{array}$ & & $\begin{array}{l}1.040^{*} \\
(0.586)\end{array}$ & \\
\hline Rauch \& Evans Index & & $\begin{array}{c}0.374 * * * \\
(0.028)\end{array}$ & & $\begin{array}{c}2.071^{* * *} \\
(0.517)\end{array}$ \\
\hline \multicolumn{5}{|l|}{ Control Variables } \\
\hline Constitutional Powers & $\begin{array}{c}0.009 \\
(0.007)\end{array}$ & $\begin{array}{c}0.032 * * * \\
(0.002)\end{array}$ & $\begin{array}{c}0.179 * * * \\
(0.034)\end{array}$ & $\begin{array}{c}0.248 * * * \\
(0.039)\end{array}$ \\
\hline $\begin{array}{l}\text { Presidents' Support } \\
\text { in Legislature }\end{array}$ & $\begin{array}{c}0.181 \\
(0.133)\end{array}$ & $\begin{array}{c}0.215 \\
(0.149)\end{array}$ & $\begin{array}{c}0.823 \\
(0.668)\end{array}$ & $\begin{array}{c}0.610 \\
(0.681)\end{array}$ \\
\hline Electoral Cycle & $\begin{array}{l}-0.002 \\
(0.001)\end{array}$ & $\begin{array}{l}-0.001 \\
(0.001)\end{array}$ & $\begin{array}{c}-0.010 * * \\
(0.004)\end{array}$ & $\begin{array}{c}-0.010^{* *} \\
(0.004)\end{array}$ \\
\hline Term Limits & $\begin{array}{l}-0.028 \\
(0.026)\end{array}$ & $\begin{array}{l}-0.031^{* *} \\
(0.014)\end{array}$ & $\begin{array}{l}-0.206 \\
(0.239)\end{array}$ & $\begin{array}{l}-0.200 \\
(0.265)\end{array}$ \\
\hline Inflation & $\begin{array}{l}-0.001 \\
(0.001)\end{array}$ & $\begin{array}{l}-0.0001 \\
(0.001)\end{array}$ & $\begin{array}{c}-0.103^{* * *} \\
(0.035)\end{array}$ & $\begin{array}{l}-0.032 \\
(0.043)\end{array}$ \\
\hline Age of democracy & $\begin{array}{l}-0.0003 \\
(0.002)\end{array}$ & $\begin{array}{c}0.005^{* *} \\
(0.002)\end{array}$ & $\begin{array}{l}-0.007 \\
(0.013)\end{array}$ & $\begin{array}{c}0.023 \\
(0.015)\end{array}$ \\
\hline Constant & $\begin{array}{l}-0.087 \\
(0.090)\end{array}$ & $\begin{array}{c}-0.982 * * * \\
(0.195)\end{array}$ & $\begin{array}{c}-4.523^{* * *} \\
(0.788)\end{array}$ & $\begin{array}{c}-8.641^{* * *} \\
(1.326)\end{array}$ \\
\hline Obs (groups) & $79(4)$ & $70(3)$ & $1090(4)$ & $996(3)$ \\
\hline Wald $\chi^{2}$ & 34.79 & 311.15 & 68.72 & 87.41 \\
\hline $\operatorname{Pr}>\chi^{2}$ & $(0.000)$ & $(0.000)$ & $(0.000)$ & $(0.000)$ \\
\hline
\end{tabular}

Note: ${ }^{* * *} \mathrm{p}<0.01,{ }^{* *} \mathrm{p}<0.05,{ }^{*} \mathrm{p}<0.1$. Robust standard errors in parentheses.

For Models 1 and 2, dependent variables are proportions of ministers from the civil service. Estimates produced using general linear models with first-order autocorrelation correction. The unit of analysis is a country-year. For Models 3 and 4, dependent variables are coded 1 if minister is from the civil service. Estimates produced using logistic regression models. The unit of analysis is an individual minister. 
FIGURE 4. Predicted Effect of the Quality of Bureaucracy on Presidential Appointments of Ministers from Civil Service

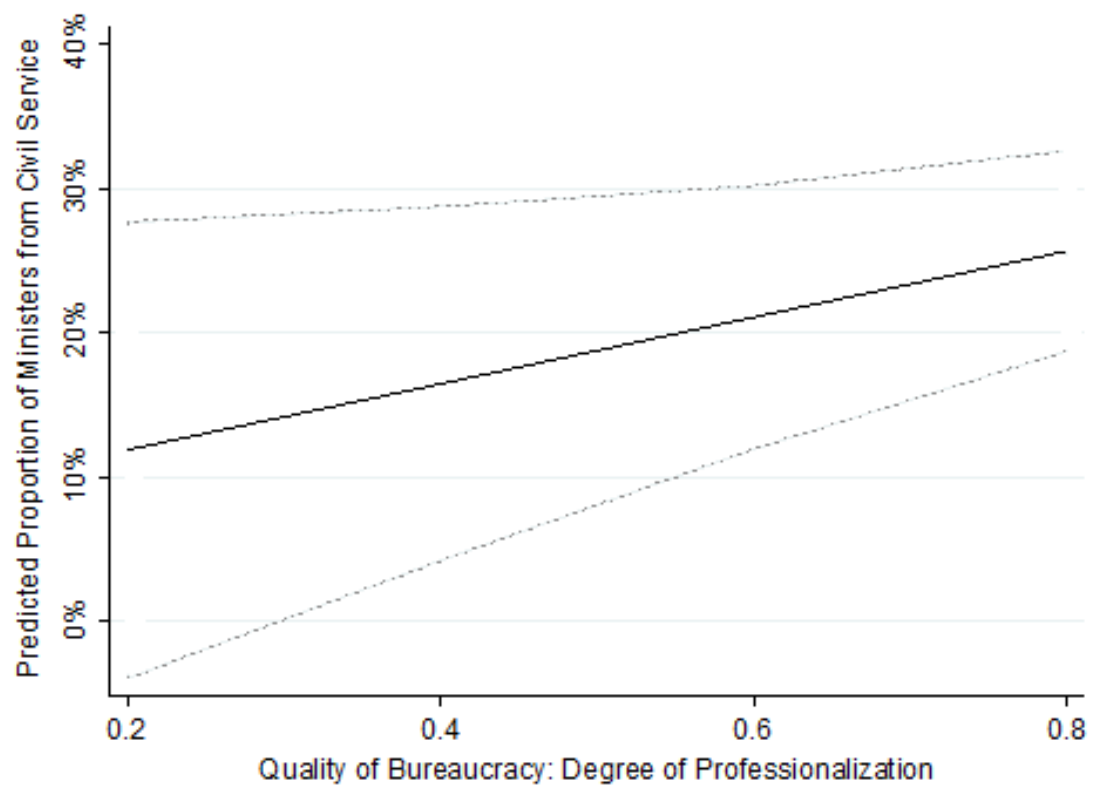

Note: Estimated values with 95 percent confidence intervals. 
TABLE 3. Major Careers of Nonpartisan Ministers from Outside the Civil Service across Administrations, Philippines and Indonesia

\begin{tabular}{ccccccc}
\hline & Professors & $\begin{array}{c}\text { Business } \\
\text { Leaders }\end{array}$ & $\begin{array}{c}\text { Military/ } \\
\text { Police }\end{array}$ & $\begin{array}{c}\text { Legal } \\
\text { Advisors }\end{array}$ & $\begin{array}{c}\text { Journalists } \\
\text { \& Others }\end{array}$ & Total \\
\hline Philippines & & & & & & \\
Aquino & 11 & 13 & 3 & 9 & 5 & 41 \\
$(1986-1992)$ & $(26.8 \%)$ & $(31.7 \%)$ & $(7.3 \%)$ & $(22.0 \%)$ & $(12.2 \%)$ & $(100 \%)$ \\
Ramos & 11 & 13 & 4 & 7 & 3 & 38 \\
$(1992-1998)$ & $(28.9 \%)$ & $(34.2 \%)$ & $(10.5 \%)$ & $(18.4 \%)$ & $(7.9 \%)$ & $(100 \%)$ \\
Estrada & 10 & 5 & 0 & 2 & 1 & 18 \\
$(1998-2001)$ & $(55.6 \%)$ & $(27.8 \%)$ & $(0.0 \%)$ & $(11.1 \%)$ & $(5.6 \%)$ & $(100 \%)$ \\
Arroyo & 21 & 12 & 9 & 8 & 2 & 52 \\
$(2001-2010)$ & $(40.4 \%)$ & $(23.1 \%)$ & $(17.3 \%)$ & $(15.4 \%)$ & $(3.8 \%)$ & $(100 \%)$ \\
Aquino III* & 5 & 9 & 1 & 4 & 1 & 20 \\
$(2010-2013)$ & $(25.0 \%)$ & $(45.0 \%)$ & $(5.0 \%)$ & $(20.0 \%)$ & $(5.0 \%)$ & $(100 \%)$ \\
Total & 58 & 52 & 17 & 30 & 12 & 169 \\
& $(34.3 \%)$ & $(30.8 \%)$ & $(10.1 \%)$ & $(17.8 \%)$ & $(7.1 \%)$ & $(100 \%)$ \\
\hline Indonesia & & & & & & \\
Wahid & 7 & 4 & 9 & 1 & 3 & 24 \\
$(1999-2001)$ & $(29.2 \%)$ & $(16.7 \%)$ & $(37.5 \%)$ & $(4.2 \%)$ & $(12.5 \%)$ & $(100 \%)$ \\
Megawati & 3 & 1 & 4 & 1 & 2 & 11 \\
$(2001-2004)$ & $(27.3 \%)$ & $(9.1 \%)$ & $(36.4 \%)$ & $(9.1 \%)$ & $(18.2 \%)$ & $(100 \%)$ \\
SBY* & 19 & 8 & 3 & 1 & 3 & 34 \\
(2004-2013) & $(55.9 \%)$ & $(23.5 \%)$ & $(8.8 \%)$ & $(2.9 \%)$ & $(8.8 \%)$ & $(100 \%)$ \\
Total & 29 & 13 & 16 & 3 & 8 & 69 \\
& $(42.0 \%)$ & $(18.8 \%)$ & $(23.2 \%)$ & $(4.3 \%)$ & $(11.6 \%)$ & $(100 \%)$ \\
\hline *Incumbent as of December 2013 & & & & &
\end{tabular}

